\title{
Elevated tumour interleukin- $\mid \beta$ is associated with systemic inflammation: a marker of reduced survival in gastro-oesophageal
}

\section{cancer}

\author{
DAC Deans', SJ Wigmore', H Gilmour', S Paterson-Brown', JA Ross' and KCH Fearon*,I \\ 'Tissue Injury and Repair Group, Department of Clinical and Surgical Sciences, MRC Centre for Inflammation Research, The Chancellor's Building, \\ Edinburgh University, 49 Little France Crescent, Edinburgh EHI6 4SB, UK
}

Systemic inflammation is associated with adverse prognosis cancer but its aetiology remains unclear. We investigated the expression of proinflammatory cytokines within normal mucosa from healthy controls and tumour tissue in cancer patients and related these levels with markers of systemic inflammation and with the presence of a tumour inflammatory infiltrate. Tissue was collected from 56 patients with gastro-oesophageal cancer and from 12 healthy controls. Tissue cytokine mRNA concentrations were measured by real-time PCR and tissue protein concentrations by cytometric bead array. The degree of chronic inflammatory cell infiltrate was recorded. Serum cytokine and acute phase protein concentrations (including C-reactive protein (CRP)) were measured by enzymelinked immunosorbent assay. Proinflammatory cytokines were significantly overexpressed (interleukin (IL)-I $\beta$, IL-6, IL-8 and tumour necrosis factor- $\alpha$ ) both at mRNA and protein levels in the cancer specimens compared with mucosa from controls. Interleukin-I $\beta$ was expressed in greatest (10-100-fold) concentration and protein levels correlated significantly with systemic inflammation (CRP) $(P=0.05, r=0.31)$. A chronic inflammatory infiltrate was observed in $75 \%$ of the cancer specimens and was associated with systemic inflammation (CRP: $P=0.0 \mathrm{I})$. However, the presence of chronic inflammation per se was not associated with altered cytokine expression within the tumour. Both a chronic inflammatory infiltrate and systemic inflammation (CRP) were associated with reduced survival $(P=0.05$ and $P=0.03$, respectively). Tumour chronic inflammatory infiltrate and tumour tissue IL-I $\beta$ overexpression are potential independent factors influencing systemic inflammation in oesophagogastric cancer patients.

British Journal of Cancer (2006) 95, I568- I575. doi: I0. I038/sj.bjc.6603446 www.bjcancer.com

Published online 7 November 2006

(c) 2006 Cancer Research UK

Keywords: inflammation; cytokines; real-time PCR

Systemic inflammation has been found in association with the majority of advanced solid epithelial malignancies and at the time of diagnosis up to $50 \%$ of patients may have an elevated acute phase protein response (APPR) (Falconer et al, 1995). The presence of an APPR has been associated with weight loss, the presence of hypermetabolism and anorexia, extent of disease, the development of recurrence in advanced cancer, and adverse prognosis (independent of stage of disease) (Rashid et al, 1982; Kodama et al, 1999; McMillan et al, 2001, 2003; Nozoe et al, 2001; Forrest et al, 2003). In patients with gastric cancer, the presence of systemic inflammation has been associated with a markedly reduced median survival ( 9 vs 53 weeks, $P<0.001$ ) (Rashid et al, 1982). Similarly, a study from Japan has identified a shortened survival in oesophageal cancer patients with an elevated serum Creactive protein (CRP) at the time of diagnosis (Nozoe et al, 2001). More recently, a group from the UK has identified elevated serum

* Correspondence: Professor $\mathrm{KCH}$ Fearon, University Department of Surgery, Royal Infirmary, 5I Little France Crescent, Edinburgh EHI6 4SA UK; E-mail: k.fearon@ed.ac.uk

Received 6 June 2006; revised 15 September 2006; accepted 26 September 2006; published online 7 November 2006
CRP and reduced serum albumin concentrations as independent prognostic indicators among patients with inoperable gastrooesophageal cancer (Crumley et al, 2006). The systemic inflammatory response is highly complex and is modulated, in part, by the interaction of pro- and anti-inflammatory cytokines. However, the precise origin of systemic inflammation among cancer patients remains obscure.

Human cancer cell lines have been shown to produce proinflammatory cytokines (Gelin et al, 1991; Strassmann et al, 1993a, b; Wigmore et al, 2002). However, such proinflammatory cytokines are not reliably detected in the circulation and probably act locally to promote inflammation and activate host inflammatory cells (e.g. peripheral blood mononuclear cells: PBMCs) passing through the tumour (Falconer et al, 1994; O'Riordain et al, 1999). Such cells can re-enter the circulation and release cytokines at distant target organs (e.g. the liver). More recently, Martignoni et al (2005) have suggested that interleukin (IL)-6 overexpression in pancreatic cancer patients is related to the ability of certain IL-6 producing tumours to sensitise PBMC and induce IL-6 expression in PBMCs. The main cytokines influencing the APPR in humans are thought to include IL-6, IL- $1 \beta$, and tumour necrosis factor- $\alpha$ (TNF- $\alpha)$ (O'Riordain et al, 1999). Interleukin-6 is the main inducer of the APPR in human 
hepatocytes and both IL- $1 \beta$ and TNF- $\alpha$ are capable of inducing IL-6 production from both tumour and host cells (Strassmann et al, $1993 \mathrm{a}, \mathrm{b})$. In cancer patients, the rates of production of IL-6 from isolated PBMCs can be linked to markers of systemic inflammation such as CRP (O'Riordain et al, 1999). The presence of such an acute phase reaction may then be used as an indirect marker of proinflammatory cytokine activity (IL- $1 \beta$, IL-6, and TNF- $\alpha$ ).

The source of the proinflammatory stimulus in advanced cancer remains unclear. It has been hypothesised that in patients with cancer, either the tumour cells or the host cells or a combination of the two are responsible for the production of the proinflammatory cytokines that induce the APPR. With a view to modulation of systemic inflammation in cancer, we hypothesise that dominant cytokines within tumour tissue drive the systemic inflammatory response and that these might be considered as targets for specific therapy. To investigate the role of tumour tissue in the genesis of systemic inflammation in cancer patients, we measured cytokine (IL- $1 \beta$, IL-6, IL- 8 , and TNF- $\alpha$ ) mRNA and protein concentrations in tumour tissue collected from patients with gastro-oesophageal cancer and tissue from healthy controls and related these measurements to systemic concentrations of cytokines and acute phase proteins (APPs). We also investigated the significance of a chronic inflammatory cellular infiltrate within these tissues and related these findings to tissue cytokine concentrations and to clinical outcome.

\section{PATIENTS AND METHODS}

\section{Study patients}

Patients diagnosed with gastric or oesophageal cancer within the Lothian and Borders regions between June 2002 and March 2004 were eligible for inclusion into the study. Patients were recruited at the time of diagnosis and all subjects provided written informed consent and the study received ethical permission from the Lothian Research Ethics Committee. All patients who had surgery were eligible and were studied. No patients were excluded or refused consent. Patients not suitable for surgical resection (advanced disease stage or comorbidity) were excluded from the study. Patients were staged according to the International Union Against Cancer (UICC), and final histopathological stage (pTNM) was used in all cases (Sobin and Wittekind, 2003). Tumours located around the oesophago-gastric junction were classified according to Siewert and those classified as types I and II were staged as oesophageal tumours and type III as gastric cancers (Siewert and Stein, 1998). All clinical and pathological information was collected prospectively, including documentation of the use of nonsteroidal anti-inflammatory drugs (NSAIDs) and any other therapeutic agents that may influence the inflammatory response.

\section{Determination of serum APP and cytokine concentrations}

A random blood was collected from patients at the time of diagnosis and before any therapeutic intervention. All patients were free from infection at the time of blood collection. Samples were collected simultaneously from 22 healthy controls for comparison. Serum was obtained by collecting whole blood into lithium-heparinised tubes and centrifuging at 2000 r.p.m. for $10 \mathrm{~min}$ at $10^{\circ} \mathrm{C}$ (Mistral 3000i, Thermo Life Sciences, Basingstoke, $\mathrm{UK})$. Aliquots were stored at $-80^{\circ} \mathrm{C}$ until batch analysis.

C-reactive protein was determined using an immunoturbidimetric assay (Abbott TDX, Abbott Laboratories, Maidenhead, UK). A level above $10 \mathrm{mgl}^{-1}$ defined the presence of an APPR. Serum albumin concentrations were measured by an automated bromocresol green dye-binding technique. The remaining APPs were determined by sandwich enzyme-linked immunosorbent assay as described previously (Wigmore et al, 2002). Briefly, 96-well plates were coated with $100 \mathrm{il}$ primary antibody (concentration $10 \mathrm{mgl}^{-1}$ ) and incubated overnight at $4^{\circ} \mathrm{C}$ (Dako, Ely, UK). The plates were washed with $0.1 \%$ Tween and diluted sera $(100 \mu \mathrm{l})$ was added to the coated wells and incubated at room temperature for $2 \mathrm{~h}$. Plates were washed as before and a secondary antibody conjugated with peroxidase was added to each well and incubated for $1 \mathrm{~h}$ (Dako, Ely, UK). The substrate used was OPD (Dako, Ely, UK) and the reaction was stopped with $0.5 \mathrm{M}$ sulphuric acid. Plates were read at $490 \mathrm{~nm}$ using a Dynatech MR5000 automated plate reader. Standard curves were generated using standard APPs supplied by the manufacturer (Dako, Ely, UK).

Serum cytokines were analysed with module kits and performed according to the manufacturers instructions (Caltag, Bender MedSystems, Towcester, UK). The lower limit of sensitivity for each assay was; $<1 \mathrm{pg} \mathrm{ml}^{-1}$ IL-1 $\beta, 1.4 \mathrm{pg} \mathrm{ml}^{-1}$ IL-6, $11 \mathrm{pg} \mathrm{ml}^{-1}$ IL-8, $0.8 \mathrm{pg} \mathrm{ml}^{-1}$ IL-10, and $5.8 \mathrm{pg} \mathrm{m}^{-1}$ TNF soluble receptor (sTNF-R).

\section{Tissue cytokine mRNA and protein measurement}

Tissue collection Tissue was obtained from 56 patients at the time of surgical resection. A representative sample of tumour tissue was collected from each patient and tissues were snap frozen in liquid nitrogen before storage at $-80^{\circ} \mathrm{C}$ until further analysis. An additional 12 patients were recruited as healthy controls. These patients underwent endoscopy as an elective procedure for investigation of dyspeptic-type symptoms. In all instances, the result of the procedure was normal, including both macroscopic and microscopic assessment. Mucosal tissue (seven oesophageal and five gastric) samples were collected from these patients with biopsy forceps at the time of endoscopy. All control subjects were considered healthy without established comorbidity or taking regular medications.

\section{Quantitative reverse transcription-polymerase chain reaction (Q-RT - PCR)}

RNA isolation and RT Total RNA was isolated from tissue samples using the RNeasy kit (Qiagen Inc., Crawley, UK). RNA quality and integrity was assessed using an Agilent 2100 bioanalyser (Agilent Technologies Ltd, Chesire, UK) in five randomly selected samples. For the remaining samples, purity and concentration were determined using spectrophotometry (Ultrospec 2000, Pharmacia Biotech, Bucks, UK). Reverse transcription was performed using $1 \mu \mathrm{g}$ of total RNA following DNase treatment (Qiagen Inc., UK). All RNA samples were checked for genomic DNA contamination before RT using conventional RTPCR. Two microlitres of total RNA was mixed with $1 \mu \mathrm{l} \mathrm{MgCl}$ $(25 \mathrm{~mm}), 2.5 \mu \mathrm{l} 10 \times$ Taq DNA polymerase buffer with added $\mathrm{MgCl}$, $2.5 \mu \mathrm{l} \mathrm{dNTP}(10 \mathrm{~mm}), 5 \mu \mathrm{l}$ forward and reverse primers $(10 \mu \mathrm{M})$, $11 \mu \mathrm{l}$ DEPC-treated water and $1 \mu \mathrm{l}$ Taq DNA polymerase $\left(5 \mathrm{U}^{-1}\right)$ (all reagents Promega, Southampton, UK). Primers for cytochrome $b$ were used to detect DNA contamination. The forward primer sequence was GGTTCTGGAATAAGAATATAGG and the reverse primer sequence GACAACACAGTAAGAACCAGG, giving a product of $367 \mathrm{bp}$ if contamination was present.

Reverse transcription was performed once DNA contamination had been excluded. The reaction mixture included the RNA ( $1 \mu \mathrm{g}$ in $10 \mu \mathrm{l}$ DEPC-treated water), $4 \mu \mathrm{l} \mathrm{MgCl}(25 \mathrm{~mm}), 2 \mu \mathrm{l} 10 \times$ reverse transcriptase buffer, $2 \mu \mathrm{l}$ dNTPs $(10 \mathrm{mM}), 1 \mu \mathrm{l}$ random hexamers $\left(500 \mu \mathrm{g} \mathrm{ml}^{-1}\right), 1.5 \mu \mathrm{l}$ AMV reverse transcriptase $\left(10 \mathrm{U}^{-1} \mathrm{l}^{1}\right)$, and $0.5 \mu \mathrm{l}$ recombinant RNase inhibitor $\left(40 \mathrm{U}^{-1} \mathrm{l}^{-1}\right)$ (all reagents Promega, Southampton, UK). Reverse transcription was performed at $42^{\circ} \mathrm{C}$ for $60 \mathrm{~min}$ followed by $95^{\circ} \mathrm{C}$ for $5 \mathrm{~min}$.

Real-time PCR Quantitative PCR was performed using the ABI PRISM 770 real-time Sequence Detection System (Applied Biosystems, Warrington, UK). Reactions were performed in $50 \mu \mathrm{l}$ 
total volume, consisting of; $25 \mu \mathrm{l}$ Taqman universal PCR master$\operatorname{mix}(\mathrm{UNG} \times 2), 14 \mu \mathrm{l}$ primer/probe mix, $2.5 \mu \mathrm{l}$ ribosomal $18 \mathrm{~S}$ primer/probe mix (all reagents Applied Biosystems, UK), $3.5 \mu \mathrm{l}$ DEPC-treated water, and $5 \mu \mathrm{l} \mathrm{cDNA.} \mathrm{Each} \mathrm{sample} \mathrm{was} \mathrm{analysed} \mathrm{in}$ duplicate. The reaction conditions were $2 \mathrm{~min}$ at $50^{\circ} \mathrm{C}, 10 \mathrm{~min}$ at $95^{\circ} \mathrm{C}$, and 40 cycles with $15 \mathrm{~s}$ at $95^{\circ} \mathrm{C}$ and $1 \mathrm{~min}$ at $60^{\circ} \mathrm{C}$. Genes studied included IL- $1 \beta$, IL-6, IL-8, and TNF- $\alpha$. The primers and probes were designed by Applied Biosystems, UK.

Quantification of gene expression was calculated using the comparative $\left(\Delta \Delta C_{\mathrm{T}}\right)$ method, where samples were compared with the positive control (Bustin, 2000). The level of gene expression within each sample was adjusted to an internal control (human ribosomal 18S) before expression was calculated as a percentage of the level of gene expression by the control sample. Samples that generated cycle numbers above 23 for the endogenous control (18S) were discarded and the samples were repeated.

Positive control Whole blood was collected from healthy donors and the white cells were isolated using histopaque (Sigma, Dorset, UK). The cells were cultured in lipo-polysaccharide (Sigma, Dorset, UK) for $48 \mathrm{~h}$ before isolation of the RNA. Total RNA was reverse transcribed as described above. Each real-time reaction used an aliquot from the stock solution of cDNA as a positive control.

Extraction of tissue protein Tissue lysates were prepared by homogenising $50 \mathrm{mg}$ of tissue in $400 \mu \mathrm{l}$ tissue homogenising buffer $\left(0.4 \mathrm{ml} 500 \mathrm{~mm}\right.$ Tris, $0.2 \mathrm{ml} 100 \mathrm{~mm}$ ATP, $1 \mathrm{ml} 50 \mathrm{~mm} \mathrm{MgCl}_{2}, 10 \mu \mathrm{l}$ dithiothreitol, $1 \times$ protease inhibitor, $8.4 \mathrm{ml}$ water - Sigma, Dorset, UK). Samples were heated to $95^{\circ} \mathrm{C}$ for $5 \mathrm{~min}$ before centrifuging at 13000 r.p.m. for $30 \mathrm{~min}$. Protein concentration of the supernatants was determined by the Bradford method (Bio-Rad, Hemel Hempstead, UK) (Bradford, 1976). Samples were stored at $-80^{\circ} \mathrm{C}$ until analysis.

\section{Determination of tissue cytokine concentrations}

Cytokine protein concentrations were determined using the Cytometric Bead Array System according to manufacturer's instructions (Human Inflammation Kit, BD Biosciences, Oxford, UK). This kit allows the measurement of cytokines IL-1 $\beta$, IL-6, IL8 , IL-10, IL-12p70, and TNF- $\alpha$. Briefly, $50 \mu \mathrm{l}$ of tissue extract was added to the reaction mix containing antibody-coated microbeads and incubated at room temperature for $3 \mathrm{~h}$. Cytokine concentrations were determined by flow cytometry (BD FACScan, Oxford, UK). Results were calculated to take into account the total protein concentration of the tissue lysate and are expressed as $\mathrm{pg} \mathrm{mg}^{-1}$ of total protein. Intra-assay variability ranged between 2 and $10 \%$ and interassay variability was $4-15 \%$.

\section{Histological analysis}

Representative sections of tumour tissue were fixed with formalin and stained with haematoxylin and eosin. A single Consultant pathologist (HG) reviewed all the tissue sections and the extent of a chronic inflammatory cellular infiltrate was recorded. Sections were classified as either diffuse scanty (occasional) chronic inflammatory cells present, focal lymphoid aggregates only, diffuse chronic inflammatory cellular infiltrate present throughout the tissue, or patchy chronic inflammatory cells present (Figure 1). HG was blinded to the clinical data, serum APP/cytokine concentrations, and tissue cytokine concentrations relating to each patient.

\section{Statistical analysis}

Comparisons between groups of continuous variables were made by the Mann-Whitney $U$-test. Categorical variables were compared by Fisher's exact test. Correlations between continuous
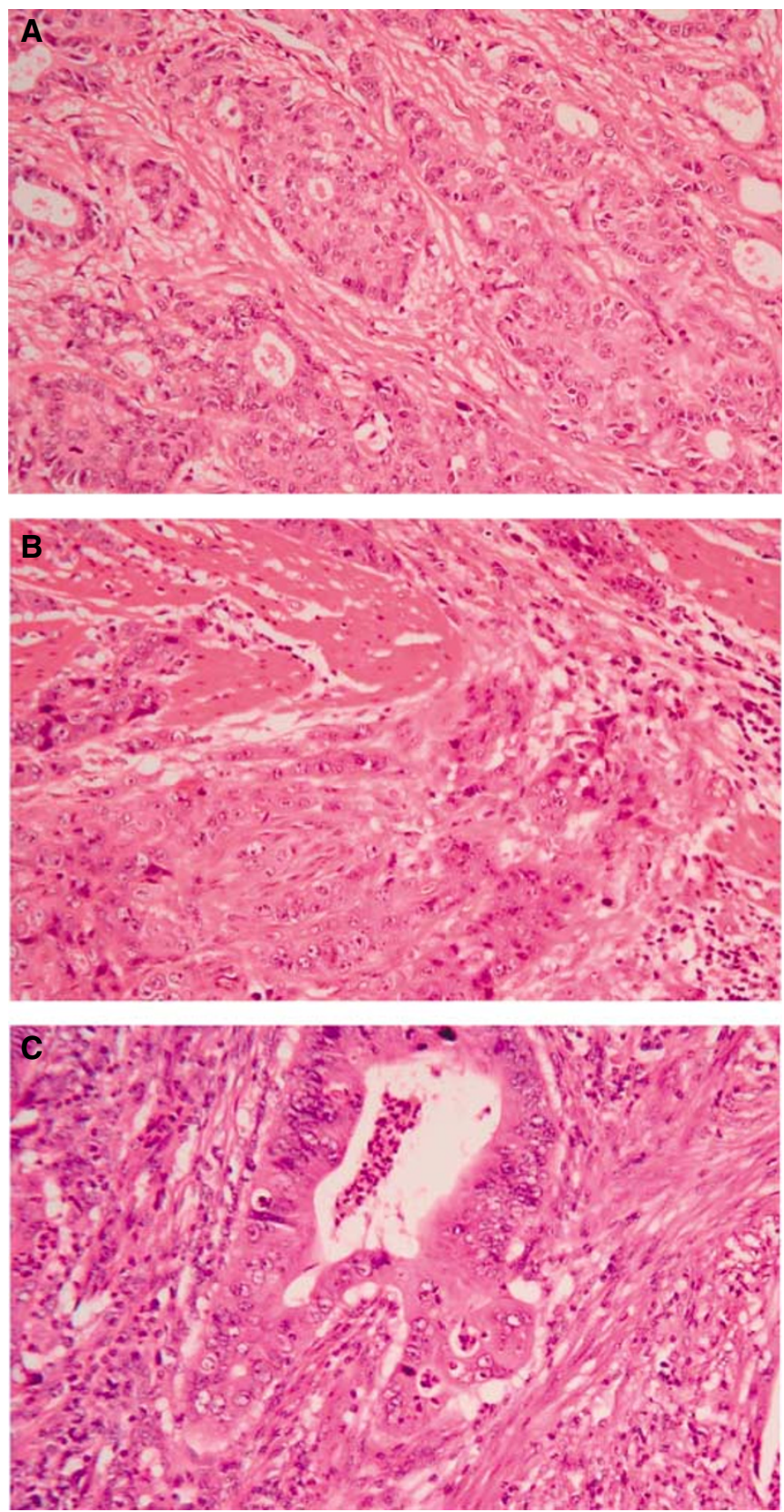

Figure I Representative photomicrographs taken from three patients with poorly differentiated adenocarcinoma of the oesophagus. Patient $(\mathbf{A})$ demonstrates minimal/no inflammatory cell reaction. Patient (B) has a patchy chronic inflammatory cell infiltrate. Patient (C) shows a diffuse chronic inflammatory cellular infiltrate present throughout the tumour Sections of tumour tissue were fixed with formalin and stained with haematoxylin and eosin (magnification $\times 100$ ).

variables were assessed by Spearman's rank correlation coefficient. Survival between groups was analysed by the log-rank test and Cox's proportional hazards model. A $P$-value $\leqslant 0.05$ was considered statistically significant.

\section{RESULTS}

\section{Study patients}

Patient demographics are shown in Table 1. Subgroup analysis confirmed no significant differences in either tissue mRNA or 
Table I Study patient demographics $(n=56)$

\begin{tabular}{lr}
\hline & Number (\%) \\
\hline Age (years) & \\
Sex & $66(58-75)$ \\
Male & $40(71)$ \\
Female & $16(29)$ \\
Tumour site & \\
Oesophageal & \\
Oesophago-gastric junction & $26(46)$ \\
Gastric & $13(23)$ \\
Histology & $17(30)$ \\
Adenocarcinoma & \\
Squamous cell carcinoma & \\
Grade & $52(93)$ \\
Well differentiated & $4(7)$ \\
Moderately differentiated & \\
Poorly differentiated & $4(7)$ \\
UICC stage & $24(43)$ \\
I & $28(50)$ \\
2 & \\
3 & $17(30)$ \\
4 & $13(23)$ \\
Treatment undertaken & $21(38)$ \\
Oesophagectomy & $5(9)$ \\
Gastrectomy & \\
Preoperative chemotherapy followed by surgery & \\
Status & $25(45)$ \\
Alive & $18(32)$ \\
Dead & $13(23)$ \\
\hline
\end{tabular}

${ }^{2} \vee$ alues given are median (interquartile range).

protein levels between patients who received preoperative chemotherapy and those who did not (data not shown). Similarly, there were no differences in tissue mRNA or protein levels or serum cytokine or APP levels among those patients taking NSAIDs or any other therapeutic agents that may modify the inflammatory response (data not shown). Therefore, all patients were included as a single group for analysis.

\section{Serum cytokine and APP concentrations}

Serum APP concentrations for the study patients and healthy controls are shown in Table 2 . The patient group had significantly elevated concentrations of positive APPs compared with the control population; CRP $(P<0.001$, Mann-Whitney $U$-test $)$, haptoglobin $(P<0.001)$, and $\alpha 1$-antichymotrypsin $(P<0.001)$. There was no difference in concentrations of the negative acute phase reactants; albumin $(P=0.242)$ or transferrin $(P=0.346)$. Ten $(18 \%)$ patients had a serum CRP concentration $>10 \mathrm{mgl}^{-1}$, which was associated with reduced survival duration $(P=0.031$, log-rank test) (Figure 2). C-reactive protein concentration remained an independent prognostic indicator on multivariate analysis when analysed with stage, age, sex, and grade $(P=0.048$, hazard ratio 2.7 (1.1-7.3 95\% CI); Cox's proportional hazards model).

Serum cytokine concentrations were similar between the healthy controls and cancer patients (Table 2). Serum cytokine concentrations did not correlate with serum APP concentrations (linear regression, data not shown) and patients with CRP levels greater than $10 \mathrm{mgl}^{-1}$ did not have significantly elevated serum cytokine concentrations.
Table 2 Serum concentrations of acute phase proteins and cytokines for the patient group $(n=56)$ and healthy controls $(n=22)$

\begin{tabular}{|c|c|c|c|}
\hline \multirow[b]{2}{*}{ CRP $(\mathrm{mg} / \mathrm{l})$} & \multicolumn{3}{|c|}{ Patient group $(n=56)$ Control group $(n=22) P$-value } \\
\hline & $4(2-16)$ & I $(1-3)$ & $<0.001$ \\
\hline Haptoglobin (mg/l) & $1869(|42|-265 \mid)$ & $821(627-1157)$ & $<0.001$ \\
\hline ACT $(\mathrm{mg} / \mathrm{l})$ & $409(326-502)$ & $245(2|3-26|)$ & $<0.001$ \\
\hline Albumin $(\mathrm{g} / \mathrm{l})$ & $42(39-44)$ & $42(39-45)$ & 0.227 \\
\hline Transferrin (mg/l) & $2076(1565-2648)$ & $2197(|86|-245 \mid)$ & 0.478 \\
\hline$|\mathrm{L}-| \beta(\mathrm{pg} / \mathrm{ml})$ & $0^{b}$ & 0 & - \\
\hline $\mathrm{IL}-6(\mathrm{pg} / \mathrm{ml})$ & $0(0-9 \mid)$ & $1 \mid(0-2 \mid 4)$ & 0.412 \\
\hline IL-8 (pg/ml) & $0(0-57)$ & $0(0-118)$ & 0.683 \\
\hline IL- $10(\mathrm{pg} / \mathrm{ml})$ & $0^{c}$ & 0 & - \\
\hline sTNF-R (ng/ml) & $2.6(1.3-4.1)$ & $2.8(1.3-3.6)$ & 0.559 \\
\hline
\end{tabular}

$\mathrm{ACT}=\alpha$-antichymotrypsin; $\quad \mathrm{CRP}=\mathrm{C}$-reactive protein; $\mathrm{IL}=$ interleukin; $\mathrm{sTNF}$ $\mathrm{R}=$ soluble tumour necrosis factor receptor ( $\mathrm{p} 55$ ). Positive acute phase protein concentrations were elevated in the patient group compared with the control group. There were no differences between concentrations of the negative acute phase reactants or serum cytokines. ${ }^{a}$ Mann-Whitney U-test. ' ${ }^{b}$ Only two patients had measurable serum IL-I $\beta$ concentrations. ${ }^{c}$ Only four patients had measurable IL- IO concentrations. Values are median (interquartile range).

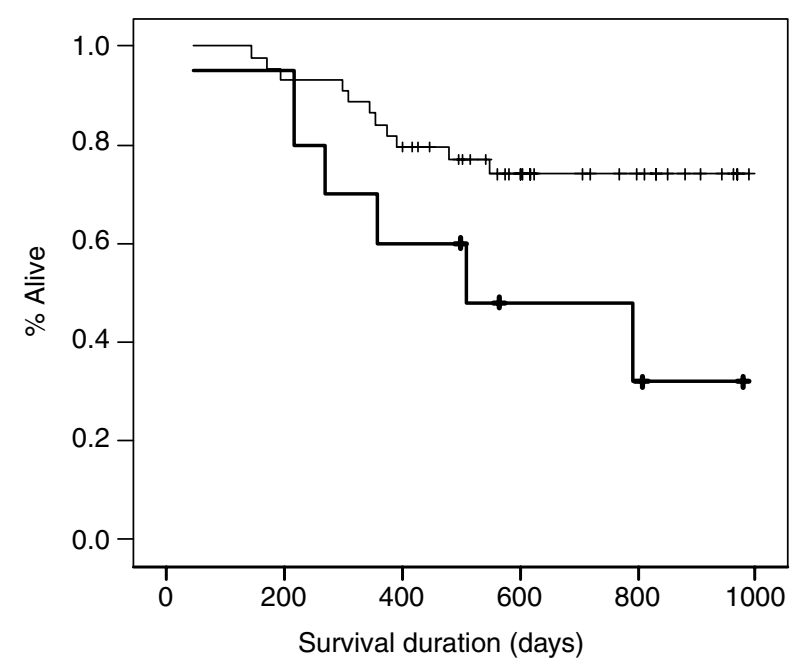

Number at risk:

$\begin{array}{lccccc}\mathrm{CRP}<10 \mathrm{mg} \mathrm{I}^{-1} 46 & 38 & 31 & 26 & 18 & 7 \\ \mathrm{CRP}>10 \mathrm{mg} \mathrm{I}^{-1} 10 & 8 & 7 & 5 & 4 & 3\end{array}$

Figure 2 Kaplan-Meier survival plot presented by serum CRP concentration. Heavy line CRP $>10 \mathrm{mg}^{-1}$ (median survival 509 days) vs light line $C R P<10 \mathrm{mgl}^{-1}$ (median survival $>900$ days); $P=0.03$ I, log-rank test.

\section{Tissue cytokine mRNA and protein concentrations}

Interleukin- 6 and IL-8 mRNA were not measurable in any of the gastro-oesophageal mucosa samples collected from healthy controls and IL- $1 \beta$ and TNF- $\alpha$ were only detectable at very low concentrations (Figure 3A). In contrast, mRNA for IL-1 $\beta$, IL-6, IL- 8 , and TNF- $\alpha$ were detected in tumour tissue at significantly elevated concentrations: IL-1 $\beta \quad P<0.001$; IL-6 $P<0.001$; IL-8 $P<0.001$; TNF- $\alpha P=0.006$ (see Figure $3 \mathrm{~A}$ ).

Similarly, IL-6 protein was not detected in mucosal tissue samples from healthy controls and IL- $1 \beta$, IL-8, and TNF- $\alpha$ were only measured at low concentrations (median concentrations; IL-1 $\beta 2.6 \mathrm{pg} \mathrm{mg}^{-1}$ total protein, IL-8 $0.2 \mathrm{pg} \mathrm{mg}^{-1}$ total protein, TNF- $\alpha 0.1 \mathrm{pg} \mathrm{mg}^{-1}$ total protein). However, cytokine protein concentrations were significantly elevated in the tumour tissue: IL-1 $\beta$ 
A

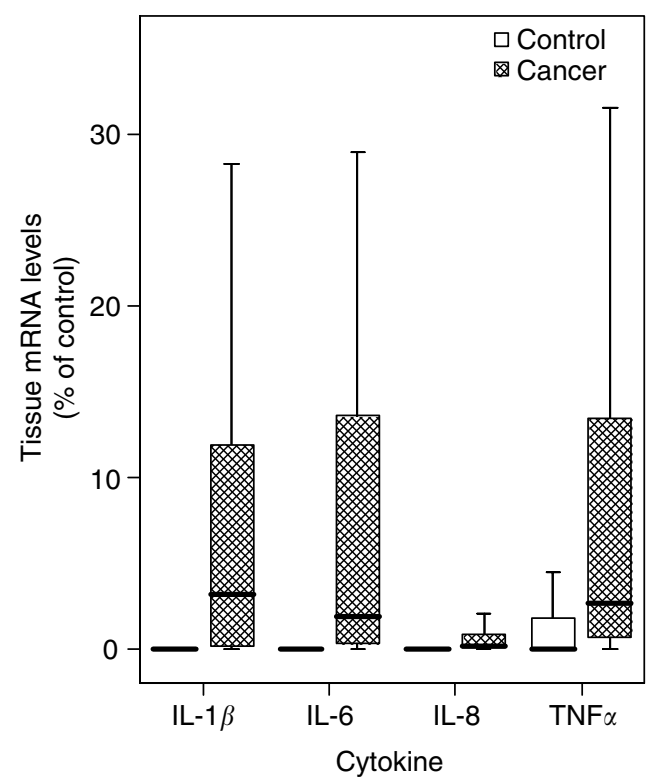

B

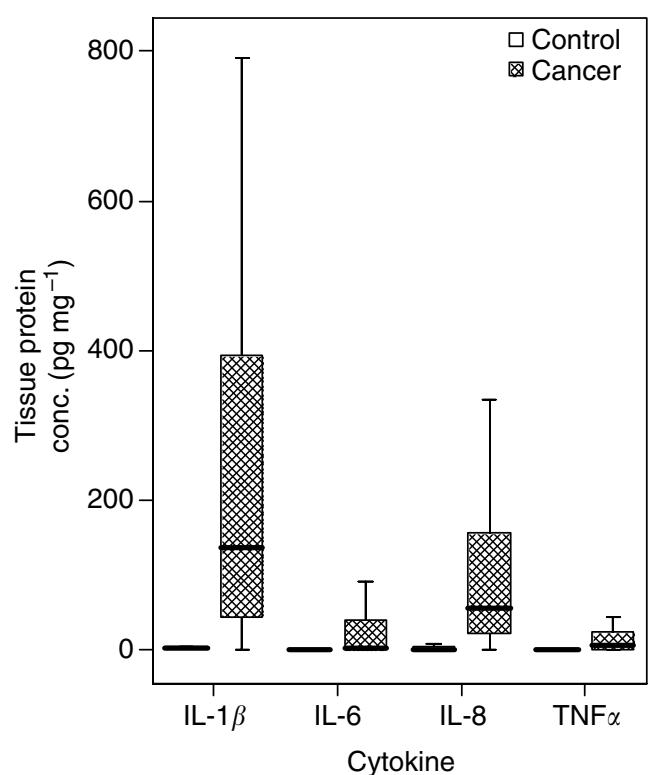

$136 \mathrm{pg} \mathrm{mg}^{-1}$ of total protein (IQR 41-425), $P=0.007$; IL-6 $3 \mathrm{pg} \mathrm{mg}^{-1}$ (IQR 0-46), $P<0.05$; IL-8 $56 \mathrm{pg} \mathrm{mg}^{-1}$ (IQR 23-159), $P=0.007$; TNF- $\alpha 7 \mathrm{pg} \mathrm{mg}^{-1}$ (IQR $\left.1-26\right), P<0.05$ (Figure 3B). Of note, IL- $1 \beta$ concentrations were found at appreciably higher concentrations compared with the other cytokines (10-100-fold increase).

There was no correlation between tissue cytokine mRNA concentrations and cytokine tissue protein concentrations; IL-1 $\beta$ $(P=0.64, r=0.07$; Spearman's rank), IL-6 $(P=0.46, r=-0.1)$, IL-8 $(P=0.55, r=0.09)$, TNF- $\alpha \quad(P=0.90, r=0.02)$. Increased mRNA concentrations were not associated with elevated tissue cytokine protein concentrations.

Tissue cytokine mRNA concentrations did not correlate with serum cytokine concentrations or serum APP concentrations (data not shown). However, tumour tissue IL-1 $\beta$ protein levels were positively correlated with serum CRP concentrations $(P=0.05$, $r=0.31$; linear regression) (Figure 4). Although TNF- $\alpha$ protein levels did not correlate with serum cytokine/APP concentrations there was a significant correlation between sTNF-R and serum CRP concentrations $(P=0.03, r=0.36)$. There was no correlation between tumour tissue IL- 6 and either circulating IL- 6 or APP concentrations. There was also a trend towards a correlation between tumour IL- 8 protein concentrations and serum sTNF-R concentrations, but this did not quite reach statistical significance $(P=0.06, r=0.32)$.

\section{Histological analysis}

Histology from three patients recruited to the study could not be traced; therefore, 53 tumour sections were studied. Twenty-four $(45 \%)$ tumour samples were classified as having scanty diffuse or patchy chronic inflammatory cells. Sixteen (30\%) tumour samples had a diffuse chronic inflammatory cellular infiltrate visible throughout the whole tumour. The remaining 13 (25\%) tumour sections had focal lymphoid aggregates only. When compared with tumour sections possessing lymphoid aggregates alone, tissues with a diffuse or patchy inflammatory cellular infiltrate were

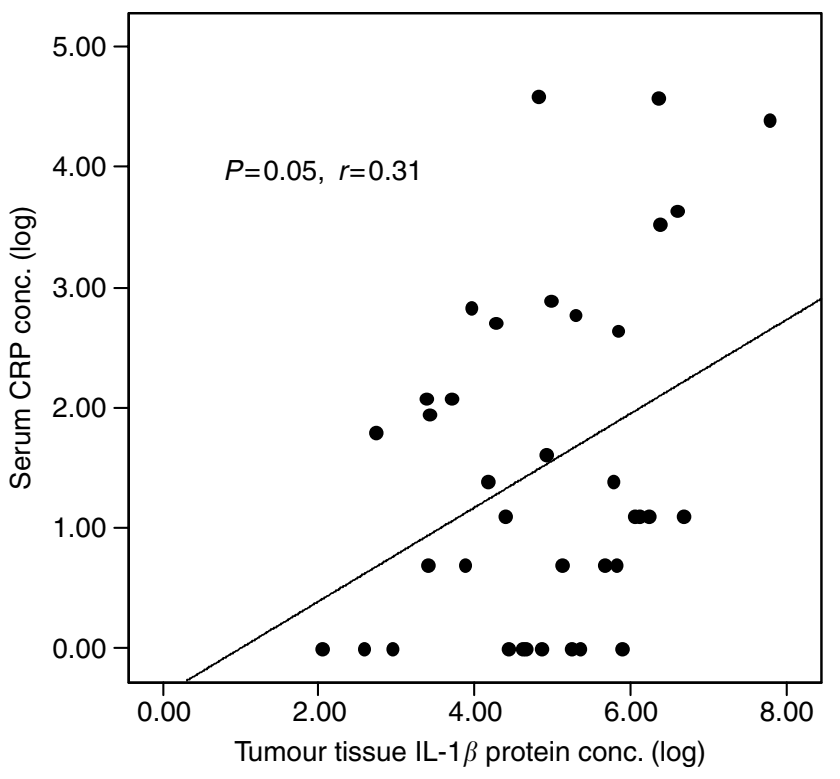

Figure 4 A scatter plot illustrating the relationship between serum CRP concentrations and tumour tissue IL-I $\beta$ protein concentrations $(P=0.05$, $r=0.31$; linear regression).

associated with elevated serum CRP and sTNF-R concentrations ( $P=0.01$ and $P=0.007$, respectively, Mann-Whitney $U$-test) (Figure 5). In addition, a chronic inflammatory cellular response was associated with reduced prognosis $(P=0.05$, log-rank test) (Figure 6). A chronic inflammatory infiltrate remained an independent prognostic indicator on multivariate analysis when analysed with stage, age, sex, tumour grade, and serum CRP concentrations $(P=0.013$, hazard ratio $7.7(1.5-38.095 \% \mathrm{CI})$; Cox's proportional hazards model). 


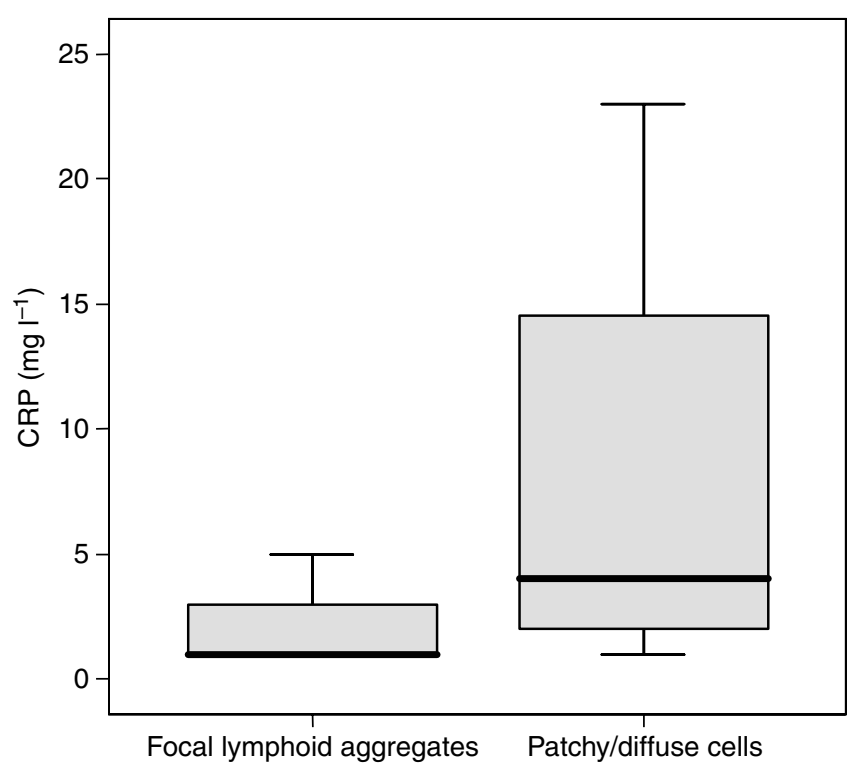

Inflammatory cell infiltrate into the tumour

Figure 5 A diffuse or patchy inflammatory cellular infiltrate was associated with elevated serum CRP concentrations $(P=0.01$. MannWhitney $U$-test). Thick bar represents median, the box represents quartiles, and lines represent extreme values.

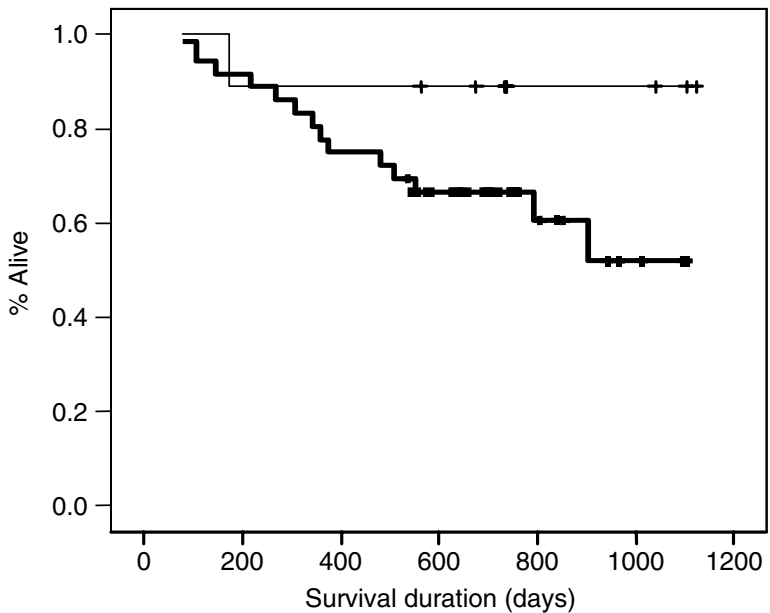

Number at risk:

$\begin{array}{lrrrccl}\text { No inflammation } & 13 & 12 & 11 & 9 & 7 & 5 \\ \text { Inflammation } & 40 & 34 & 27 & 22 & 15 & 5\end{array}$

Figure 6 Kaplan-Meier survival plot presented by the presence or absence of a chronic inflammatory cellular infiltrate within the tumour. The heavy line represents the presence of a chronic inflammatory infiltrate vs focal lymphoid aggregates alone, light line ( $P=0.05$; log-rank test).

There was no correlation between the presence of a chronic inflammatory cell infiltrate and serum cytokine concentrations.

Six (11\%) patients had histological evidence of Helicobacter pylori on the resected specimens. A chronic inflammatory cellular infiltrate was not associated with $H$. pylori infection $(P=0.67$, Fisher's exact test).

Tumour necrosis was evident in 13 (25\%) samples, including four samples collected from patients who received preoperative chemotherapy, but there was no association between treatment modality and the presence of tumour necrosis $\left(P=0.92, \chi^{2}\right.$ test $)$. The presence of tumour necrosis was associated with elevated serum haptoglobin but not CRP concentrations $(P=0.045$ and $P=0.07$, respectively, Mann-Whitney $U$-test). Tumour necrosis was not associated with differences in tissue cytokine concentrations or survival $(P=0.62$, log-rank test).

Tissue cytokine (IL- $1 \beta$, IL- 6 , IL- 8 , and TNF- $\alpha$ ) mRNA and protein levels were found at similar concentrations within tumour tissues with a chronic inflammatory cell infiltrate and tumour samples with lymphoid aggregates alone.

\section{DISCUSSION}

In this study, we have shown that patients with gastro-oesophageal malignancy have elevated serum concentrations of APPs but similar serum proinflammatory cytokine concentrations compared with a control population. A range of proinflammatory cytokine concentrations (mRNA and protein) were significantly elevated in tumour tissue compared with tissue sampled from healthy controls. However, only IL- $1 \beta$ correlated with markers of systemic inflammation (CRP). In addition, a chronic inflammatory cellular infiltrate within the tumour was associated with elevated serum APP concentrations and reduced survival, but was not associated with elevated tissue cytokine mRNA and protein concentrations.

An APPR has been well documented among patients with cancer, including gastric and oesophageal malignancies, and an elevated serum CRP has been identified as an adverse prognostic indicator, independent of stage of disease, among these patients (Rashid et al, 1982; Falconer et al, 1995; Kodama et al, 1999; McMillan et al, 2001, 2003; Nozoe et al, 2001; Forrest et al, 2003). The present study has confirmed these findings. Patients with gastro-oesophageal cancer had significantly elevated serum concentrations of positive APPs compared with healthy controls. Moreover, the $10(18 \%)$ patients with a CRP concentration above $10 \mathrm{mgl}^{-1}$ at diagnosis had a reduced survival interval, which was independent of disease stage. Our study did not demonstrate any differences in serum cytokine concentrations between cancer patients and controls. Although some studies have shown an association between serum cytokines and APPs (Martignoni et al, 2005) several have failed to demonstrate such a link and determination of serum cytokines remains an unreliable measure of tissue cytokine activity (Falconer et al, 1994; Barber et al, 1999). Moreover, these findings suggest that circulating cytokines may not be the key mediators of the APPR.

Proinflammatory cytokine mRNA and protein concentrations were either not detectable or found at low levels in tissue collected from healthy controls. In contrast, mRNA and cytokine protein concentrations were measured at significantly higher concentrations in tumour tissue. In all instances, tissue cytokine concentrations were significantly elevated in tumour tissue compared with tissue from healthy controls. These findings are supported by Yuan et al (2000) who investigated IL-8 mRNA concentrations in tumour tissue and adjacent normal lung tissue among patients with nonsmall-cell lung cancer and also found increased cytokine expression within the tumour tissue. Other groups have similarly demonstrated increased tissue cytokine concentrations associated with progression along the metaplasia-dysplasia-carcinoma sequence in Barrett's oesophagus (Tselepis et al, 2002; Dvorakova et al, 2004).

In the present study, median IL- $1 \beta$ concentrations were $10-100$ fold higher than IL- 6 in the tumour tissue and there was a weak but significant correlation between tumour tissue IL- $1 \beta$ concentration and serum CRP. There was a similar trend with IL-8. Both IL-1 $\beta$ and IL- 8 are recognised as important cytokines in the generation of the systemic inflammatory response and it is possible that high tissue concentrations of these cytokines stimulate PBMCs as they pass through the tumour mass, which in turn act on target organs, 
such as the liver, to induce the synthesis of APPs that are associated with systemic inflammation. Previously, we have demonstrated that PBMC from weight-losing pancreatic cancer patients control the hepatic APPR by a primarily IL-6-dependent mechanism (O'Riordain et al, 1999). Moreover, Martignoni et al (2005) have suggested that IL-6 overexpression in cachectic pancreatic cancer patients is related to the ability of certain IL-6 producing tumours to sensitise PBMC and induce IL-6 expression in PBMCs. In the latter study, screening by DNA microassay analysis followed by quantitative PCR identified only IL-6 mRNA expression to be significantly increased in tumour samples of cachectic patients compared with noncachectic patients or pancreas samples from normal controls. Immunohistochemistry suggested the source of IL- 6 to be tumour cells rather than host cells. The results of the present study, however, identify that at least in patients with gastro-oesophageal cancer IL- $1 \beta$ rather than IL-6 may be important as an initiator of the proinflammatory APPR. Interleukin-6 may form a common final pathway via activated PBMCs. Interestingly, in the colon-26 murine model of cancer cachexia associated with systemic inflammation there appears to be a complex intratumoural amplification loop between IL-1 $\beta$ and IL-6, which can be downregulated by IL-10 (Yasumoto et al, 1995; Fujiki et al, 1997).

In this study, we did not find any correlation between tissue cytokine mRNA concentrations and systemic cytokines or APP concentrations. Raddatz et al (2005) did identify an association between tissue cytokine mRNA levels and systemic CRP concentrations in Crohn's disease. These differing results may be partly explained by the lack of correlation between tissue mRNA concentrations and protein concentrations in this study. Although some groups have demonstrated a correlation between IL- $1 \beta$ and IL-6 mRNA and protein concentrations in an animal model of inflammatory joint disease, they also failed to show any correlation for TNF- $\alpha$ mRNA and protein concentrations (Rioja et al, 2004). The difficulties of relating mRNA concentrations to protein concentrations has been extensively documented elsewhere, but it is also important to consider that real-time PCR is an exquisitely sensitive technique and that what we are detecting in some patients, although elevated, may have little or no functional significance as it may not be translated into protein. Cytokine protein concentrations are, therefore, likely to be a more robust measure of tissue cytokine activity than mRNA levels.

A chronic inflammatory cellular infiltrate was noted in 40 (75\%) tumour samples and was associated with elevated levels of serum CRP and sTNF-R. In addition, a chronic inflammatory infiltrate was associated with reduced survival. The presence of an inflammatory infiltrate within tumours and its relevance to prognosis has been investigated in a number of cancer types. Tumour-associated macrophages have been associated with reduced disease-free survival among lung, head and neck, and endometrial cancer (Marcus et al, 2004; Ohno et al, 2004; Chen et al, 2005). In contrast, increased numbers of tumour-associated macrophages, eosinophils, mast cells, and lymphocytes have been linked with improved survival in colorectal cancer (Svennevig et al, 1984; Jass, 1986; Nielsen et al, 1999). The prognostic significance of tumour-associated inflammatory cells is less clear in gastro-oesophageal cancer. An increased macrophage infiltrate was associated with more advanced stage of disease among patients with gastric cancer in one study, whereas other studies have suggested a more favourable prognosis associated with a more pronounced macrophage infiltration (Heidl et al, 1987; Tsujitani et al, 1987; Ohno et al, 2003). Similarly, increasing tumour-infiltrating lymphocyte count has been linked with decreased risk of death from gastric cancer in one study, but associated with an adverse prognosis in another (Setala et al, 1996; Grogg et al, 2003). Studies relating to oesophageal cancer are equally contradictory (Ma et al, 1999; Koide et al, 2004). In this study, there were no differences in tissue cytokine concentrations (mRNA or protein) between tumours with a chronic inflammatory infiltrate and those without, suggesting that differential tissue IL- $1 \beta$ expression is likely to be tumour-cell derived.

Laser capture microdissection (LCM) enables single cell types to be separated from multiple cell populations and would have been helpful in separating our tissue samples into pure tumour cell and inflammatory cell populations (Emmert-Buck et al, 1996). This technique was attempted initially but abandoned owing to inconsistent results, which were related to poor RNA quality as a consequence of this technique. In addition, our results have shown a lack of correlation between mRNA levels and functional protein concentrations, questioning the relevance of measuring mRNA concentrations. Determining cellular cytokine protein concentrations by the cytometric bead array system following LCM was not possible owing to the low protein concentrations that were retrieved.

Tumour necrosis was evident in $25 \%$ of tissue samples and was not associated with receipt of preoperative chemotherapy. The presence of tissue necrosis was weakly associated with elevated serum APP concentrations and may be explained by the necrotic tissue behaving like an abscess and inducing a predominantly acute inflammatory response. Tissue necrosis did not have any prognostic value in this study.

In conclusion, systemic inflammation is associated with adverse prognosis in gastro-oesophageal cancer. Tumour tissue cytokine concentrations are elevated compared with healthy controls and IL- $1 \beta$ concentrations are positively associated with some markers of systemic inflammation. In addition, the presence of a chronic inflammatory cell infiltrate into the tumour is also associated with markers of systemic inflammation and reduced survival, but is not associated with differential expression of tissue preinflammatory cytokine concentrations. This raises the possibility that the role of the chronic inflammatory infiltrate in the generation of systemic inflammation may be independent of differential expression of proinflammatory cytokines by these cells. Different mediators or cell-cell interactions may be more important for their effects.

\section{ACKNOWLEDGEMENTS}

We thank Mr Andrew de Beaux, Consultant Surgeon, Edinburgh Royal Infirmary, for his help in the recruitment of patients and provision of assistance with the clinical aspects of this work. We also thank Ms Kathryn Sangster for her excellent technical advice and assistance.

\section{REFERENCES}

Barber MD, Fearon KC, Ross JA (1999) Relationship of serum levels of interleukin-6, soluble interleukin-6 receptor and tumour necrosis factor receptors to the acute-phase protein response in advanced pancreatic cancer. Clin Sci (London) 96(1): 83-87

Bradford M (1976) A rapid and sensitive method for the quantitation of microgram quantities of protein utilizing the principle of protein-dye binding. Anal Biochem 72: 248-254
Bustin SA (2000) Absolute quantification of mRNA using real-time reverse transcription polymerase chain reaction assays. J Mol Endocrinol 25: $169-193$

Chen JJ, Lin YC, Yao PL, Yuan A, Chen HY, Chien CT, Chen WJ, Lee YT, Yang PC (2005) Tumour-associated macrophages: the double-edged sword in cancer progression. J Clin Oncol 23(5): $953-964$ 
Crumley ABC, McMillan DC, McKernan M, McDonald AC, Stuart RC (2006) Evaluation of an inflammation-based prognostic score in patients with inoperable gastro-oesophageal cancer. Br J Cancer 94(5): 637-641

Dvorakova K, Payne CM, Ramsey L, Holubec H, Sampliner R, Dominguez J, Dvorak B, Bernstein H, Bernstein C, Prasad A, Fass R, Cui H, Garewal H (2004) Increased expression and secretion of interleukin-6 in patients with Barrett's esophagus. Clin Cancer Res 10(6): 2020-2028

Emmert-Buck M, Bonner R, Smith P, Chuaqui RF, Zhuang Z, Goldstein SR, Weiss RA, Liotta LA (1996) Laser capture microdissection. Science 274: $998-1001$

Falconer JS, Fearon KCH, Ross JA, Elton R, Wigmore SJ, Garden OJ, Carter DC (1995) Acute phase protein response and survival duration of patients with pancreatic cancer. Cancer 75(8): 2077-2082

Falconer JS, Fearon KCH, Plester CE, Ross JA, Carter DC (1994) Cytokines, the acute phase response, and resting energy expenditure in cachectic patients with pancreatic cancer. Ann Surgery 219(4): 325-331

Forrest LM, McMillan DC, McAdrle CS, Angerson WJ, Dunlop DJ (2003) Evaluation of cumulative prognostic scores based on the systemic inflammatory response in patients with non-operable non-small-cell lung cancer. Br J Cancer 89(6): $1028-1030$

Fujiki F, Mukaida N, Hirose K, Ishida H, Harada A, Ohno S, Bluethmann H, Kawakami M, Akiyama M, Sone S, Matsushima K (1997) Prevention of adenocarcinoma colon 26 -induced cachexia by interleukin 10 gene transfer. Cancer Res 57: 94-99

Gelin J, Moldawer LL, Lonnroth C, Sherry B, Chizzonite R, Lundholm K (1991) Role of endogenous TNF $\alpha$ and IL-1 for experimental tumour growth and the development of cancer cachexia. Cancer Res 51(1): $415-421$

Grogg KL, Lohse CM, Pankratz VS, Halling KC, Smyrk TC (2003) Lymphocyte-rich gastric cancer: associations with Epstein-Barr virus, microsatellite instability, histology, and survival. Mol Pathol 16(7): $641-651$

Heidl G, Davaris P, Zwadlo G, Jagoda MS, Duchting S, Bierhoff E, Gruter T, Krieg V, Sorg C (1987) Association of macrophages detected with monoclonal antibody $25 \mathrm{~F} 9$ with progression and pathobiological classification of gastric carcinoma. J Cancer Res Clin Oncol 113(6): $567-572$

Jass JR (1986) Lymphocytic infiltration and survival in rectal cancer. J Clin Pathol 39(6): 585-589

Kodama J, Miyagi Y, Seki N, Tokumo K, Yoshinouchi M, Kobashi Y, Okuda H, Kudo T (1999) Serum C-reactive protein as a prognostic factor in patients with epithelial ovarian cancer. Eur J Obstet Gynaecol Reprod Biol 82(1): $107-110$

Koide N, Nishio A, Sato T, Sugiyama A, Miyagawa S (2004) Significance of macrophage chemoattractant protein-1 expression and macrophage infiltration in squamous cell carcinoma of the esophagus. Am J Gastroenterol 99(9): $1667-1674$

Ma Y, Xian M, Li J, Kawabata T, Okada S (1999) Interrelations of clinicopathological variables, local immune response and prognosis in esophageal squamous cell carcinoma. APMIS 107(5): 514-522

Marcus B, Arenberg D, Lee J, Kleer C, Chepeha DB, Schmalbach CE, Islam L, Paul S, Pan Q, Hanash S, Kuick R, Merajver SD, Teknos TN (2004) Prognostic factors in oral cavity and oropharyngeal squamous cell carcinoma. Cancer 101(12): 2779-2787

Martignoni ME, Kunze P, Hildebrandt W, Kunzli B, Berberat P, Giese T, Kloters O, Hammer J, Buchler MW, Giese NA, Friess H (2005) Role of mononuclear cells and inflammatory cytokines in pancreatic cancerrelated cachexia. Clin Cancer Res 11: 5802-5808

McMillan DC, Elahi MM, Sattar N, Angerson WJ, Johnstone J, McArdle CS (2001) Measurement of the systemic inflammatory response predicts cancer-specific and non-cancer survival in patients with cancer. Nutr Cancer 41: 64-69

McMillan DC, Canna K, McArdle CS (2003) Systemic inflammatory response predicts survival following curative resection of colorectal cancer. Br J Surgery 90: 215-219
Nielsen HJ, Hansen U, Christensen IJ, Reimert CM, Brunner N, Moesgaard F (1999) Independent prognostic value of eosinophil and mast cell infiltration in colorectal cancer tissue. J Pathol 189(4): 487-495

Nozoe T, Saeki H, Sugimachi K (2001) Significance of preoperative elevation of CRP as an indicator of prognosis in oesophageal carcinoma. Am J Surg 182: $197-201$

Ohno S, Inagawa $\mathrm{H}$, Dhar DK, Fujii T, Ueda S, Tachibana M, Suzuki N, Inoue M, Soma G, Nagasue N (2003) The degree of macrophage infiltration into the cancer cell nest is a significant predictor of survival in gastric cancer patients. Anticancer Res 23(6D): 5015-5022

Ohno S, Ohno Y, Suzuki N, Kamei T, Koike K, Ingawa H, Kohchi C, Soma G, Inoue M (2004) Correlation of histological localization of tumorassociated macrophages with clinicopathological features in endometrial cancer. Anticancer Res 24(5C): 3335-3342

O'Riordain MG, Falconer JS, Maingay J, Fearon KC, Ross JA (1999) Peripheral blood cells from weight-losing cancer patients control the hepatic acute phase response by a primarily interleukin- 6 dependent mechanism. Int J Oncol 15(4): 823-827

Raddatz D, Bockemuhl M, Ramadori G (2005) Quantitative measurement of cytokine mRNA in inflammatory bowel disease: relation to clinical and endoscopic activity and outcome. Eur J Gastroenterol Hepatol 17(5): $547-557$

Rashid SA, O'Quigley J, Axon A, Cooper EH (1982) Plasma protein profiles and prognosis in gastric cancer. Br J Cancer 45: $390-394$

Rioja I, Bush KA, Buckton JB, Dickson MC, Life PF (2004) Joint cytokine quantification in two rodent arthritis models: kinetics of expression, correlation of mRNA and protein levels and response to prednisolone treatment. Clin Exp Immunol 137(1): 65-73

Setala LP, Kosma VM, Marin S, Lipponen PK, Eskelinen MJ, Syrjanan KJ, Alhava EM (1996) Prognostic factors in gastric cancer: the value of vascular invasion, mitotic rate and lymphoplasmacytic infiltration. $\mathrm{Br} \mathrm{J}$ Cancer 74(5): 766-772

Siewert JR, Stein HJ (1998) Classification of adenocarcinoma of the oesophagogastric junction. Br J Surgery 85: 1457-1459

Sobin LH, Wittekind CH (2003) TNM Classification of Malignant Tumours 6th edn. John Wiley, London

Strassmann G, Fong M, Freter CE, Windsor S, D'Alessandro F, Nordan RP (1993a) Suramin interferes with IL-6 receptor binding in vitro and inhibits colon-26-mediated experimental cancer cachexia in vivo. J Clin Invest 92(5): $2152-2159$

Strassmann G, Masui Y, Chizzonite R, Fong M (1993b) Mechanisms of experimental cancer cachexia. Local involvement of IL-1 in colon-26 tumour. J Immunol 150(6): 2341-2345

Svennevig JL, Lunde OC, Holter J, Bjotgsvik D (1984) Lymphoid infiltration and prognosis in colorectal carcinoma. Br J Cancer 49(3): 375-377

Tselepis C, Perry I, Dawson C, Hardy R, Darnton SJ, McConkey C, Stuart RC, Wright N, Harrison R, Jankowski JA (2002) Tumour necrosis factoralpha in Barrett's oesophagus: a potential novel mechanism of action. Oncogene 21(39): 6071-6081

Tsujitani S, Furukawa T, Tamada R, Okamura T, Yasumoto K, Sugimachi K (1987) Langerhans cells and prognosis in patients with gastric carcinoma. Cancer 59(3): 501-505

Wigmore SJ, Fearon KC, Sangster K, Maingay JP, Garden OJ, Ross JA (2002) Cytokine regulation of constitutive production of interleukin- 8 and -6 by human pancreatic cancer cell lines and serum cytokine concentrations in patients with pancreatic cancer. Int J Oncol 21(4): 881-886

Yasumoto K, Mukaida N, Harada A, Kuno K, Akiyama M, Nakashima E, Fujioka N, Mai M, Kasahara T, Fujimoto-Ouchi K (1995) Molecular analysis of the cytokine network involved in cachexia in colon 26 adenocarcinoma-bearing mice. Cancer Res 55: 921 - 927

Yuan A, Yang PC, Yu CJ, Chen WJ, Lin FY, Kuo SH, Luh KT (2000) Interleukin-8 messenger ribonucleic acid expression correlates with tumor progression, tumor angiogenesis, patient survival, and timing of relapse in non-small-cell lung cancer. Am J Respir Crit Care Med 162(5): $1957-1963$ 